\title{
Serum prolactin concentrations in mangabey (Cercocebus atys lunulatus) and patas (Erythrocebus patas) monkeys in response to stress, ketamine, TRH, sulpiride and levodopa
}

\author{
D. Aidara, C. Tahiri-Zagret and C. Robyn
}

Department of Biology and Animal Physiology, Université Nationale de Côte d'Ivoire, Abidjan, Ivory Coast, and Human Reproduction Research Unit, Université Libre de Bruxelles, Hôpital

Saint-Pierre, Belgium

\begin{abstract}
Summary. An homologous radioimmunoassay for human serum prolactin was validated to measure serum prolactin in 10 mangabey and 7 patas monkeys. Mean basal levels of serum prolactin were almost identical in the males of both species and in immature and mature males. However, basal levels were higher in females than in males.

Serum prolactin was enhanced by stress, i.v. injection of TRH and intramuscular injection of a potent dopamine antagonist (sulpiride). The rise in serum prolactin observed after i.m. injection of ketamine hydrochloride used as anaesthetic was of small amplitude and short duration. Oral administration of levodopa was followed by a significant fall in serum prolactin. Sexual maturity did not influence the responses to TRH or sulpiride. The mangabeys were more sensitive to sulpiride but less sensitive to levodopa than were the patas monkeys.

The variations in serum prolactin levels observed in these monkeys under the influence of stress, TRH, sulpiride and levodopa are similar to those observed in man to the same stimuli, although the experimental conditions were quite different.
\end{abstract}

\section{Introduction}

The mangabey (Cercocebus atys lunulatus) and patas (Erythrocebus patas) monkeys are very common cercopithecids in Ivory Coast. The mangabey lives in the forest of the south and the patas in the savannah of the north. There are several advantages to using these monkeys for experimental work on non-human primates: they are of small size ( $10 \mathrm{~kg}$ body weight maximum for the adult male) and the mangabey particularly is not aggressive and is easy to tame.

The present study was conducted to validate a radioimmunoassay for cercopithecid prolactin by using a homologous radioimmunoassay for human prolactin. The effects of stress and analgesia on serum prolactin were also investigated.

\section{Materials and Methods}

\section{Animal handling}

The animals in the study were 3 mature mangabey females $(5800-6270 \mathrm{~g}), 2$ immature $(3470$ and $3850 \mathrm{~g})$ and 5 mature $(6450-10450 \mathrm{~g})$ mangabey males, and 4 immature 
(3880-5780 g) and 3 mature (7660-9350 g) patas males. The distinction between immature and mature males was based on the work of Hall, Boelkins \& Goswell (1965) and Tahiri-Zagret (1973) who considered that the males of these two species are mature at a body weight of $>6500$ g. The 3 females were regularly menstruating.

The monkeys were housed in Abidjan in open-air wire-netted cages $(3 \times 3 \times 2 \mathrm{~m})$ covered by a straw roof. Each cage contained no more than 3 animals. Females and males were kept in separate cages. In this space, the monkeys were exposed to variations in temperature and light and dark alternations similar to those of their natural environment. The diet consisted of rice, vegetables, fruit, meat and fish. The animals had free access to drinking water.

When tests were performed, the monkeys were isolated and confined in smaller cages $(80 \times$ $80 \times 60 \mathrm{~cm}$ ) equipped with a moving panel to immobilize the animal for intramuscular injections or for collection of daily blood samples. When blood samples had to be collected at frequent intervals, the monkeys were injected intramuscularly with ketamine hydrochloride (Ketalar; Parke Davis) at $5 \mathrm{mg} / \mathrm{kg}$ body weight. This dose of ketamine was not enough to induce narcosis but was sufficient to immobilize the animals for a few minutes and facilitate installation in a restraint chair. A catheter was inserted into a saphenous vein and the first sample of blood was collected 120 min before injection or oral administration of the test substance. Coagulation was prevented by injection of $0.1 \mathrm{ml} 1 \%$ heparin solution in saline after each sample collection. Each time blood was taken, the first $0.2 \mathrm{ml}$ was discarded.

\section{Serum samples}

Blood samples were first kept at room temperature $\left( \pm 20^{\circ} \mathrm{C}\right)$ for $3 \mathrm{~h}$. After centrifugation, serum was transferred into glass tubes $(10 \times 70 \mathrm{~mm})$ and merthiolate was added $(1 / 10000 \mathrm{w} / \mathrm{v}$, final concentration). The serum samples were kept at $-20^{\circ} \mathrm{C}$ until hormone assay. The samples were transferred from Abidjan to Brussels surrounded by solid carbon dioxide in a container insulated with plastic foam. All samples from the same animal and from the same test, including the controls, were measured in the same assay.

\section{Hormone assay}

Serum prolactin was measured as previously described by a double-antibody radioimmunoassay method (Robyn, L'Hermite, Petrusz \& Diczfalusy, 1971; Badawi, Bila, L'Hermite, Perez-Lopez \& Robyn, 1974) using the VLS-2 reagents (Aubert, Becker, Saxena \& Raiti, 1974) distributed by the National Institute of Arthritis, Metabolism and Digestive Diseases (National Institutes of Health, U.S.A.). Non-specific binding of iodinated prolactin was $3 \%$ both in buffer and in serum. Specific binding of iodinated prolactin to the diluted antiserum ( $1 / 400000$ final dilution) was $25 \%$ of the total dose of tracer.

A pool of serum samples collected from women during early post partum was used as laboratory standard and tested against the human pituitary prolactin research standard M.R.C. 71/222 (National Institute for Biological Standards and Control, London): no deviation from parallelism occurred between the dose-response curves and $1 \mu \mathrm{l}$ of the laboratory standard contained $2.3 \mu \mathrm{U}$ of the M.R.C. 71/222 standard (Cotes, 1973). Pools of sera collected from mangabey and patas monkeys after injection of TRH or sulpiride were tested against the human serum prolactin standard (Text-fig. 1). No significant deviation from parallelism occurred between the dose-response curves obtained with monkey serum prolactin and that obtained with human serum prolactin. All the monkey prolactin measurements were therefore expressed in terms of $\mu \mathrm{U}$ of the M.R.C. $71 / 222$ standard. The sensitivity of the assay was $10 \mu \mathrm{U} / \mathrm{ml}$. In the range of the values obtained in this study, the within-assay coefficient of variation was $9.7 \%$ and the between-assay coefficient of variation was $15 \cdot 5 \%$. 


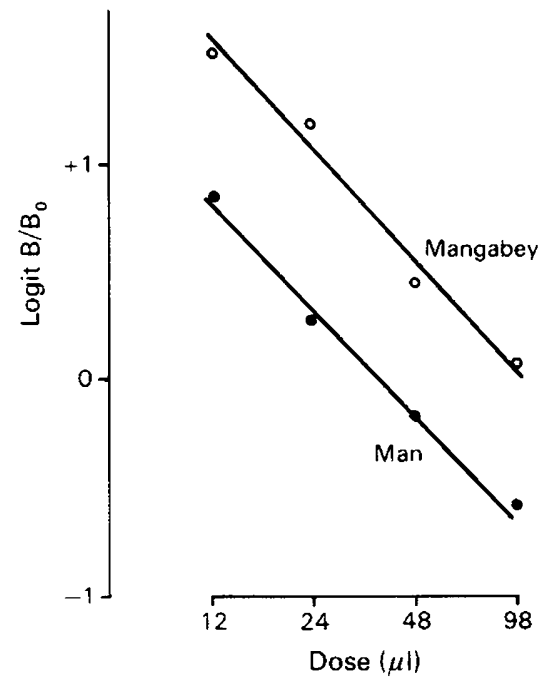

Text-fig. 1. Dose-responses curves obtained with the laboratory standard of human serum prolactin and with a pool of mangabey serum in a radioimmunoassay for human prolactin using the reagents (VLS-2) distributed by the NIAMDD, NIH, U.S.A.. The laboratory standard ( $1 \mu$ l) contains $2 \cdot 3 \mu \mathrm{U}$ of the human pituitary prolactin research standard M.R.C. 71/222.

\section{Tests}

The influence of stress (Text-fig. 2) was investigated by catching the monkey from a large cage in a net at 0 min without pretreatment with ketamine: blood samples were taken at frequent intervals during $3 \mathrm{~h}$.

The influence of ketamine hydrochloride $(10 \mathrm{mg} / \mathrm{kg}$ body weight), TRH (Farbwerke Hoechst AG, Frankfort, Germany; $4.5 \mu \mathrm{g} / \mathrm{kg}$ body weight), sulpiride (Delagrange Laboratories, Paris, France; $2 \mathrm{mg} / \mathrm{kg}$ body weight) and levodopa (Roche, Basle, Switzerland; $10 \mathrm{mg} / \mathrm{kg}$ body weight) on serum prolactin was tested by taking biood samples at frequent intervals before and after administration of the drug. All injections were performed $2 \mathrm{~h}$ after insertion of the catheter in the saphenous vein.

\section{Statistical analysis}

The distribution of serum prolactin levels was checked in each group by the Rankit test (Martin, 1973): it was found to be log-normal and all values were transformed to logarithms. Homogeneity of variances was evaluated by the Bartlett test (Snedecor, 1956). The statistical significance of differences between groups was evaluated by two-way variance analyses ( $F$ tests) as described by Snedecor (1956).

\section{Results}

A summary of the results is given in Table 1.

\section{Stress}

As shown in Text-fig. 2, the mean serum prolactin level in the first sample collected after insertion of the intravenous catheter was about 2 -fold greater $(F=23.89 ; P<0.001)$ than that $3 \mathrm{~h}$ later. The greatest part of the decline occurred within $45 \min (\mathrm{F}=9.61 ; P<0.01)$ and the 
Table 1. Differences between basal levels of serum prolactin and between serum prolactin responses to ketamine, TRH, sulpiride and levodopa, according to sexual maturity, species and sex in the patas and mangabey monkeys

\begin{tabular}{|c|c|c|c|c|c|c|c|c|c|}
\hline & \multicolumn{9}{|c|}{ Mean serum prolactin values $(\mu \mathrm{U} / \mathrm{ml})$} \\
\hline & \multicolumn{3}{|c|}{ Sexual maturity } & \multicolumn{3}{|c|}{ Species } & \multicolumn{3}{|c|}{ Sex } \\
\hline & $\begin{array}{c}\text { Immature } \\
\delta^{\alpha}\end{array}$ & $\begin{array}{c}\text { Mature } \\
\sigma^{*}\end{array}$ & $\mathbf{F}$ & $\begin{array}{c}\text { Patas } \\
\sigma^{x}\end{array}$ & $\begin{array}{c}\text { Mangabey } \\
\delta\end{array}$ & $\mathbf{F}$ & Mangabey & $\begin{array}{c}\text { Mangabey } \\
\delta\end{array}$ & $\mathbf{F}$ \\
\hline \multicolumn{10}{|l|}{ Ketamine } \\
\hline Basalt & 356 & 322 & $\begin{array}{l}0.01 \\
(99)\end{array}$ & 329 & 340 & $\begin{array}{l}0.30 \\
(99)\end{array}$ & 423 & 340 & $\begin{array}{l}4 \cdot 37^{*} \\
(66)\end{array}$ \\
\hline \multicolumn{10}{|l|}{ Test } \\
\hline$(15-30 \mathrm{~min})$ & 462 & 462 & $\begin{array}{l}0.00 \\
(99)\end{array}$ & 483 & 462 & $\begin{array}{l}0 \cdot 32 \\
(99)\end{array}$ & 517 & 462 & $\begin{array}{l}0.60 \\
(66)\end{array}$ \\
\hline \multicolumn{10}{|l|}{ TRH } \\
\hline Basalt & 297 & 274 & $\begin{array}{l}0.40 \\
(90)\end{array}$ & 274 & 297 & $\begin{array}{l}0.98 \\
(90)\end{array}$ & 480 & 297 & $\begin{array}{l}19 \cdot 17^{* * * *} \\
(54)\end{array}$ \\
\hline \multicolumn{10}{|l|}{ Test } \\
\hline (5-90 min) & 476 & 492 & $\begin{array}{l}0 \cdot 19 \\
(90)\end{array}$ & 469 & 506 & $\begin{array}{l}0.98 \\
(90)\end{array}$ & 837 & 506 & $\begin{array}{l}48 \cdot 70^{* * * *} \\
(54)\end{array}$ \\
\hline \multicolumn{10}{|l|}{ Sulpiride } \\
\hline Basalt & 375 & 327 & $\begin{array}{l}2.45 \\
(90)\end{array}$ & 368 & 324 & $\begin{array}{l}2 \cdot 15 \\
(90)\end{array}$ & 391 & 324 & $\begin{array}{l}1 \cdot 24 \\
(54)\end{array}$ \\
\hline \multicolumn{10}{|l|}{ Test } \\
\hline$(5-90 \mathrm{~min})$ & 842 & 773 & $\begin{array}{l}2 \cdot 13 \\
(90)\end{array}$ & 727 & 908 & $\begin{array}{l}14 \cdot 74^{* * *} \\
(90)\end{array}$ & 950 & 909 & $\begin{array}{l}0.41 \\
(54)\end{array}$ \\
\hline \multicolumn{10}{|l|}{ Levodopa } \\
\hline Basalt & - & - & - & 313 & 297 & $\begin{array}{l}0 \cdot 19 \\
(77)\end{array}$ & - & - & - \\
\hline $\begin{array}{l}\text { Test } \\
\quad(60-240 \mathrm{~min})\end{array}$ & - & - & - & 184 & 269 & $\begin{array}{l}21 \cdot 50^{* * * *} \\
(77)\end{array}$ & - & - & - \\
\hline
\end{tabular}

Statistical significance of the differences was evaluated by $F$ tests for the d.f. indicated in parentheses: ${ }^{*}<0.05, * * *<<0.001$. + From -120 to $0 \mathrm{~min}$.

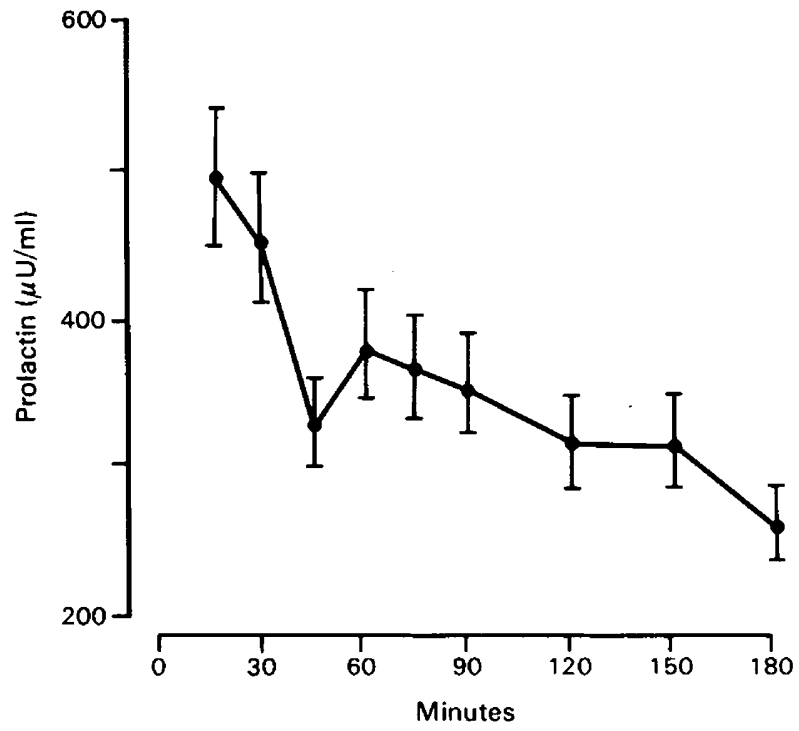

Text-fig. 2. Mean \pm s.e.m. serum prolactin concentrations in 5 mature male mangabey monkeys after capture in the cage, installation in a restraint chair and insertion of an i.v. catheter. 
values at 45 and $180 \mathrm{~min}$ were not significant $(P>0.05)$. There was no significant difference in the values within the first $90 \mathrm{~min}$ or those at $120-180 \mathrm{~min}$ between immature (425 and 317 $\mu \mathrm{U} / \mathrm{ml})$ and mature (368 and $278 \mu \mathrm{U} / \mathrm{ml}$ ) animals.

\section{Ketamine hydrochloride}

Intramuscular injection of $10 \mathrm{mg}$ ketamine hydrochloride $/ \mathrm{kg}$ (Text-fig. 3) resulted in a small (1.5-fold) increase of serum prolactin within $30 \mathrm{~min}(\mathrm{~F}=24.42 ; P<0.001)$. There were no significant differences in the magnitude of the rise in serum prolactin levels between patas and mangabey monkeys (Table 1), between mature and immature monkeys (Table 1) or between males and females (Table 1 and Text-fig. 3). Within $3 \mathrm{~h}$ (Text-fig. 3), the serum levels were again within the limits of the control values before the injection $(\mathrm{F}=1.92 ; P>0.05)$. Basal levels were significantly higher in females than in males (Table 1).

(a)
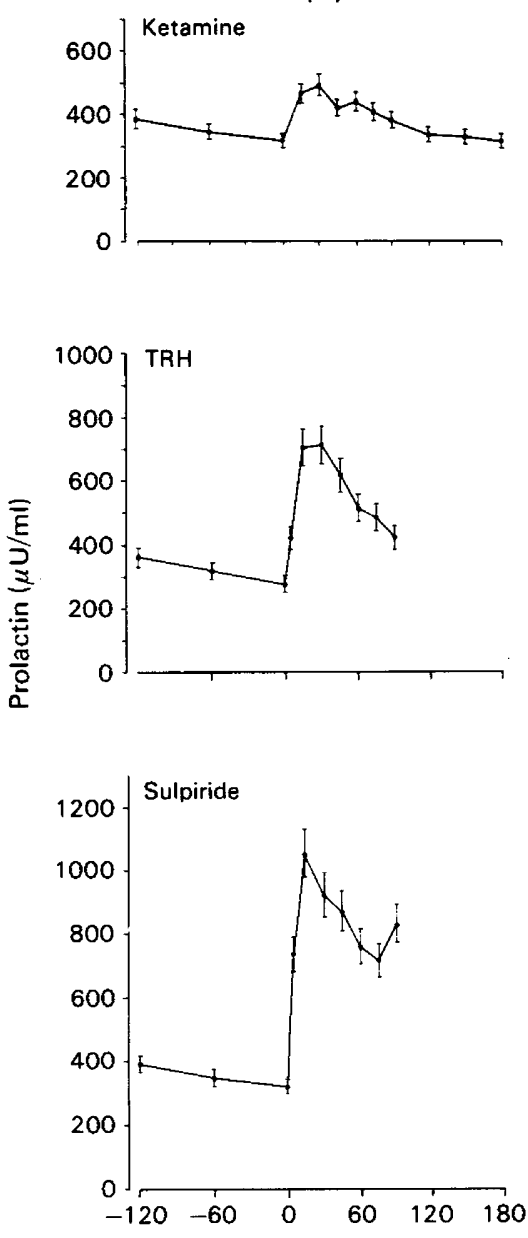

(b)
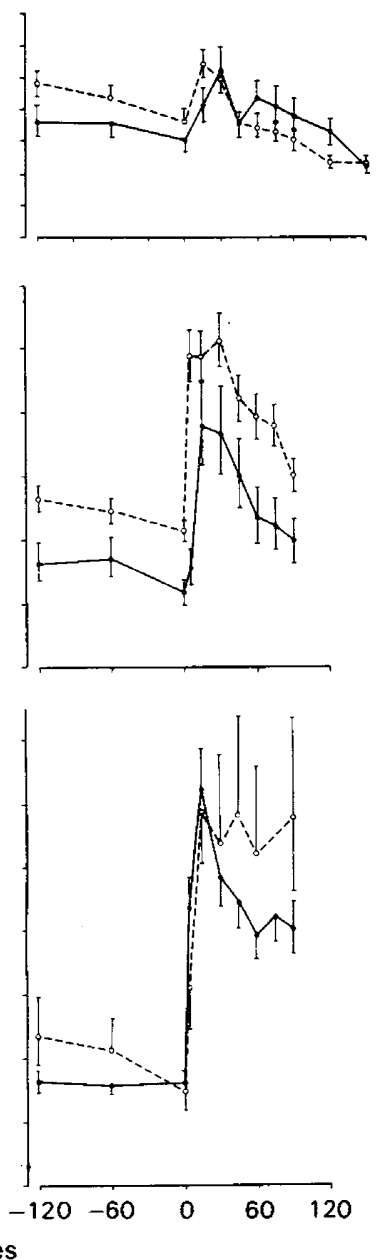

Text-fig. 3. Mean \pm s.e.m. serum prolactin concentrations in (a) 14 mangabey and patas monkeys and (b) 3 mature female $\left(\mathrm{O}^{--} \mathrm{O}\right)$ and 4 mature male $(\longrightarrow)$ mangabeys before and after i.m. injection of $10 \mathrm{mg}$ ketamine $/ \mathrm{kg}$, i.v. injection of $4.5 \mu \mathrm{g} \mathrm{TRH} / \mathrm{kg}$ and i.m. injection of $2 \mathrm{mg}$ sulpiride $/ \mathrm{kg}$ at $0 \mathrm{~min}$. The significance of the differences between males and females is indicated in Table 1. 


\section{Thyrotrophin-releasing hormone}

Intravenous injection of TRH (Text-fig. 3) was followed within 5 min by a significant increase of serum prolactin $(\mathrm{F}=4.60 ; P<0.05)$ and the maximal value $(2.6$-fold greater than at $0 \mathrm{~min}$ ) was obtained by $15 \mathrm{~min}$. Thereafter, serum prolactin declined progressively (Text-fig. 3 ) and after $90 \mathrm{~min}$ the mean value was still significantly higher than the control level at $0 \mathrm{~min}(\mathrm{~F}$ $=9.75 ; P<0.01$ ).

There was no effect of species or sexual maturity on the response to TRH (Table 1), but basal levels and the responses to TRH were significantly higher in female than in male mangabeys (Table 1 and Text-fig. 3).

\section{Sulpiride}

The intramuscular injection of sulpiride (Text-fig. 3) was followed within 5 min by a significant increase in serum prolactin $(\mathrm{F}=59.85 ; P<0.01)$ which reached maximum levels at $15 \mathrm{~min}$ (Text-fig. 3). Prolactin concentrations declined slowly and at $90 \mathrm{~min}$ the values were still very high. The size of the response was greater among the patas than among the mangabeys (Table 1), but there were no apparent differences between immature and mature animals or males and females (Table 1 and Text-fig. 3).

\section{Levodopa}

Oral administration of levodopa (Text-fig. 4) was followed within $1 \mathrm{~h}$ by a significant decrease of serum prolactin levels $(\mathrm{F}=21.32 ; P<0.001)$. The minimal value was observed after $4 \mathrm{~h}$. Thereafter, serum prolactin rose progressively and returned after $7 \mathrm{~h}$ to levels similar to those obtained before treatment (Text-fig. 4). All mangabey males were more sensitive than patas males (Text-fig. 4) but 2 of the 3 mangabeys were immature and their responses to levodopa, if any, were very small.

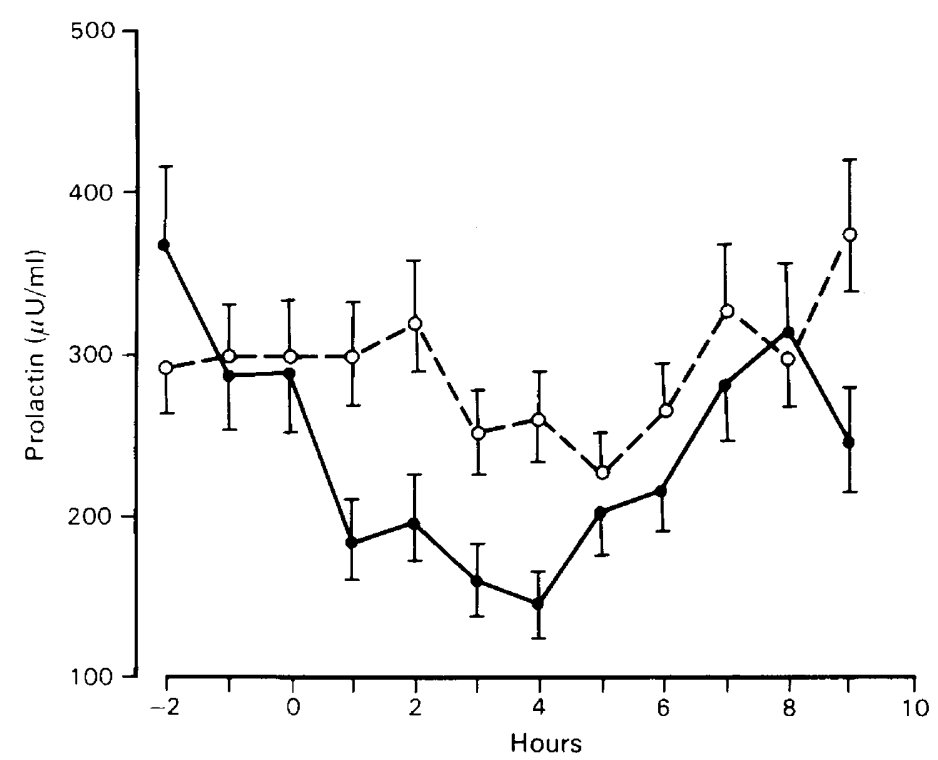

Text-fig. 4. Mean \pm s.e.m. serum prolactin concentrations in 5 male patas $\left(\mathrm{O}_{---0}\right)$ and 3 male mangabey (-) monkeys before and after oral administration of levodopa $(10 \mathrm{mg} / \mathrm{kg}$ body weight at $0 \mathrm{~min}$ ). The significance of the differences between patas and mangabeys is indicated in Table 


\section{Discussion}

An homologous radioimmunoassay for human prolactin (VLS, NIAMDD, NIH, U.S.A.) has been applied for the measurement of serum prolactin from two cercopithecid monkeys (patas and mangabey) of Africa (Ivory Coast). Dose-response curves obtained with monkey serum prolactin were parallel to those obtained with human serum prolactin and statistically valid radioimmunoassays were thus obtained. This is in agreement with data by Josimovich, Weiss \& Hutchinson (1974), who have validated a similar homologous human assay for the measurement of serum prolactin in the rhesus monkey, another cercopithecid monkey. Serum prolactin levels (mean and $95 \%$ confidence limits) obtained by radioimmunoassay were $340 \mu \mathrm{U} / \mathrm{ml}(635-187)$ in male and $423 \mu \mathrm{U} / \mathrm{ml}(953-189)$ in female mangabey and patas monkeys. These values are somewhat higher than those reported by Vekemans \& Robyn (1975): $239 \mu \mathrm{U} / \mathrm{ml}$ (488-117) for men and $333 \mu \mathrm{U} / \mathrm{ml}(795-140)$ for women.

Stress increases serum prolactin levels in these cercopithecids: capturing the animal with a net and inserting an intravenous catheter were followed by a rise in serum prolactin for $1-2 \mathrm{~h}$.

Intramuscular injection of ketamine hydrochloride was followed by a small $(1 \cdot 5$-fold) and transient rise of serum prolactin levels. The stress related to the intramuscular injection itself could have been the cause of this increase. In rats, this drug has little or no effect on plasma prolactin levels (Lawson \& Gala, 1974).

Serum prolactin rose as quickly after i.v. injection of TRH as after i.m. injection of sulpiride. However, the prolactin response to sulpiride was greater and more prolonged than the response to TRH. Similar data were reported for man (Robyn, 1976). Both drugs are known to stimulate prolactin secretion (Schally, Arimura \& Kastin, 1973; Delvoye et al., 1975), but the way they act is different. The effects of TRH are mediated by specific TRH receptors on TSH and prolactin cells (see Robyn, 1976). Sulpiride is a potent dopamine antagonist, also acting directly on the lactotrophs (McLeod \& Robyn, 1977); it suppresses the permanent inhibition exerted on the lactotrophs by the dopamine produced by the hypothalamus and transferred to the pituitary by the portal vessels.

Oral administration of levodopa is followed by a progressive but prolonged $(5-6 \mathrm{~h})$ decline of serum prolactin levels. Such inhibition by levodopa on prolactin secretion has been reported for man (Frantz et al., 1973; Rozencweig, Heuson, Bila, L’Hermite \& Robyn, 1973).

The sex of the monkeys influences basal levels of serum prolactin and the responses to prolactin releasers as reported for man (Jacobs \& Daughaday, 1973; Vekemans \& Robyn, 1975): both the basal values and the amplitude of the responses are greater in females than in males. This is due to the effects of oestrogens on the lactotrophs. In rats, oestrogens increase prolactin release and synthesis; they also stimulate mitosis in the lactotrophs (Jacobi, Lloyd \& Meares, 1977). The influence of oestrogens on prolactin secretion in man is well documented. In monkeys, the data reported are contradictory. Some authors have not observed any stimulatory effect of oestrogens (Butler, Krey, Lu, Peckham \& Knobil, 1975) but others have done so (El Etreby \& Günzel, 1974; Herbert, Schuppler, Poggel, Günzel \& El Etreby, 1977; Milmore, 1978).

Mangabeys were more sensitive to sulpiride than were patas monkeys, but less sensitive to levodopa. This may reflect differences in the dopaminergic control of prolactin secretion between these two cercopithecid species.

We thank Mrs J. Delogne-Desnoeck, M. A. Machgeels and H. Preszow for technical assistance, and the NIAMDD for the VLS reagents used for the prolactin assay. The expenses of the investigations were covered by research grants from the Fonds National Belge de la Recherche Scientifique (No. 3.4531.77). 


\section{References}

Aubert, M.L., Becker, R.L., Saxena, B.B. \& Raiti, S. (1974) Report of the National Pituitary Agency. Collaborative study of the radioimmunoassay of human prolactin. J. clin. Endocr. Metab. 38, 11151120.

Badawi, M., Bila, S., L'Hermite, M., Perez-Lopez, F.R. \& Robyn, C. (1974) Comparative evaluation of radioimmunoassay methods for human prolactin using anti-ovine and anti-human prolactin sera. In Radioimmunoassay and Related Procedures in Medicine, vol. 1, pp. 411-420. International Atomic Energy Agency, Vienna.

Butler, W.R., Krey, L.C., Lu, K.-H., Peckham, W.D. \& Knobil, E. (1975) Surgical disconnection of the medial basal hypothalamus and pituitary function in the rhesus monkey. Tome 4. Prolactin secretion. Endocrinology 95, 1099-1105.

Cotes, P.M. (1973) Research Standard A for human prolactin (in ampoules coded 71/222). In Human Prolactin, pp. 97-101. Eds J. L. Pasteels \& C. Robyn. Excerpta Medica (I.C.S. No. 308), Amsterdam.

Delvoye, P., Taubert, H.-D., Jürgensen, O., L'Hermite, M., Delogne, J. \& Robyn, C. (1975) Evolution des gonadotrophines et de la progesterone sériques au cours d'une hyperprolactinémie induite par le sulpiride (Dogmatil ${ }^{R}$ ) pendant la phase lutéale du cycle menstruel. J. Pharmacol. Clin. 2, 121-124.

El Etreby, M.F. \& Günzel, P. (1974) Sex hormoneseffects on prolactin cells in the rat, dog, monkey and man. Acta endocr., Copenh., Suppl. 189, 3-15.

Frantz, A.G., Habif, D.V., Hyman, G.A., Suh, H.K., Sassin, J.F., Zimmerman, E.A., Noel, G.L. \& Kleinberg, D.L. (1973) Physiological and pharmacological factors affecting prolactin secretion, including its suppression by L-Dopa in the treatment of breast cancer. In Human Prolactin, pp. 273-290. Eds J. L. Pasteels \& C. Robyn. Excerpta Medica (I.C.S. No. 308), Amsterdam.

Hall, K.R., Boelkins, R.C. \& Goswell, M.J. (1965) Behaviour of patas monkey in captivity with notes on the natural habitat. Folia primat. 3, 22-49.

Herbert, D.C., Schuppler, J., Poggel, A., Günzel, P. \& El Etreby, M.F. (1977) Effect of cyproterone acetate on prolactin secretion in the female rhesus monkey. Cell Tiss. Res. 183, 51-60.

Jacobi, J., Lloyd, H.M. \& Meares, J.D. (1977) Onset of oestrogen-induced prolactin secretion and DNA synthesis by the rat pituitary gland. J. Endocr. 72 , 35-39.

Jacobs, L.S. \& Daughaday, W.H. (1973) Pathophysio- logy and control of prolactin secretion in patients with pituitary and hypothalamic disease. In Human Prolactin, pp. 189-205. Eds J. L. Pasteels \& C. Robyn. Excerpta Medica (I.C.S. No. 308), Amsterdam.

Josimovitch, J.B., Weiss, G. \& Hutchinson, D.L. (1974) Sources and disposition of pituitary prolactin in maternal circulation, amniotic fluid and placenta in the pregnant rhesus monkey. Endocrinology 94, 1364-1371.

Lawson, D.M. \& Gala, R.R. (1974) The influence of surgery, time of day, blood volume reduction and anaesthetics on plasma prolactin in ovariectomized rats. J. Endocr. 62, 75-83.

Martin, L. (1973) Methodes Statistiques Médicales, 2nd edn. Presses Universitaires de Bruxelles.

McLeod, R.M. \& Robyn, C. (1977) On the mechanism of increased prolactin secretion by sulpiride. $J$. Endocr. 72, 273-277.

Milmore, J.E. (1978) Influence of ovarian hormones on prolactin release in the Rhesus monkey. Biol. Reprod. 19, 593-596.

Robyn, C. (1976) Interrelations between prolactin and the hypothalamo-hypophysio-thyroid axis: a review. In Ist Int. Symp. on Basic Applications and Clinical Uses of Hypothalamic Hormones, pp. 319-342. Eds A. L. Charro-Salgado, R. Fernandez-Durango \& J. G. Lopez del Campo. Excerpta Medica (I.C.S. No. 374), Amsterdam.

Robyn, C., L'Hermite, M., Petrusz, P. \& Diczfalusy, E. (1971) Potency estimates of human gonadotrophins by a bioassay and three immunoassay methods. Acta endocr., Copenh. 67, 417-433.

Rozencweig, M., Heuson, J.C., Bila, S., L'Hermite, M. \& Robyn, C. (1973) Effect of 2-Br-a-ergocryptine, L-Dopa and cyclic imides on serum prolactin in post-menopausal women. Eur. J. Cancer 9, 657-664.

Schally, A.V., Arimura, A. \& Kastin, A.J. (1973) Hypothalamic regulatory hormones. Science, N.Y. 179, 341-350.

Snedecor, G.W. (1956) Statistical Methods Applied to Experiments in Agriculture and Biology, 5th edn. lowa University Press, Ames.

Tahiri-Zagret, C. (1973) Recherches cytophysiologiques sur la fonction gonadotrope de l'adénohypophyse mâle des Cercopithécidae. Annls Univ. Abidjan, Série C, 30-31.

Vekemans, M. \& Robyn, C. (1975) Influence of age on serum prolactin levels in women and men. Br. med.J. 4, 738-739.

Received 6 August 1980 